\title{
Estimation of SWCC for Unsaturated Soils and Its Application to Design of Shallow Foundations
}

\author{
Hamzah M. Beakawi Al-Hashemi \\ Department of Civil and Environmental Engineering, King Fahd University of Petroleum and Minerals \\ Dhahran 31261, Eastern Province, Saudi Arabia \\ G201552950@kfupm.edu.sa
}

\begin{abstract}
The importance of unsaturated soil mechanics stems from the fact that the majority of geotechnical engineering projects are taking place in unsaturated soil zones. Soil suction, especially matric suction, is controlling the unsaturated soil behavior. However, measurements and determination of the soil suction is still a concern for geotechnical engineers and researchers regarding its accuracy, practicality, cost, and reliability. In this study, the filter paper method (FPM) has been adopted as a secondary indirect measurement of the suction. Both total and matric suction were measured for three different mixtures of coarse soil (sand) and fine soil (industrial Bentonite/Montmorillonite) at two different saturation levels for each mixture. An extensive characterization has been conducted for the soil samples and, thereafter, samples were prepared at $95 \%$ of the maximum dry density (MDD) on wet and dry sides of optimum for suction measurements. The soil-water-characteristic/retention curve (SWCC/SWRC) was then completed for each sample using an estimation method reported in the literature. A new prediction model has been developed, in this study to determine a fitting parameter for estimating SWCC. Also, a review on the application of SWCC to design of shallow foundations has been presented in a simplified manner. Finally, recommendations for future work and conclusions were reported.
\end{abstract}

Keywords: SWCC, Unsaturated, Bearing Capacity, SEM, XRD, Sand, Montmorillonite, Image Processing.

\section{Introduction}

The SWCC for soil is a relationship between the matric suction (chemical potential) and the water content (gravimetric or volumetric) or the saturation degree (S). The first SWCC's were obtained by Edgar Buckingham in 1907 for six different soils varying from sand to clay [1]. The SWCC is mandatory to evaluate the different behavior of unsaturated or partially saturated soil in terms of strength, stiffness, conductivity, serviceability, etc. In order to obtain the SWCC, the matric suction of soil should be measured, against the water content or saturation degree. Both direct and indirect measurements of soil suction exist and have been highlighted in the literature. Typical examples include Thermocouple Psychrometers, Transistor Psychrometers, Chilled-Mirror Psychrometers, Filter Paper Method, Thermal or Electrical Conductivity Sensor, among others [2], [3]. The filter paper method, as a secondary indirect measurement technique, is used in this study due to its capability in the determination of both total and matric suction [4], [5]. In geotechnical engineering, the matric suction is of greater concern than total suction, which is defined as the pressure that tends to equalize the moisture content in a soil block, and equal to the difference between pore air $\left(\mathrm{u}_{\mathrm{a}}\right)$ and (negative) water $\left(\mathrm{u}_{\mathrm{w}}\right)$ pressures.

\section{Experimental Program}

Tests were conducted on sand-montmorillonite mixtures with different percentages of montmorillonite (MMT), i.e., $2 \%, 4 \%$, and $6 \%$. The sandy soil was collected from Half-Moon beach in the city of Khobar, Saudi Arabia, while the MMT samples were acquired from a local manufacturer who provided the MMT for borehole-drilling applications. Both the sand and MMT were characterized independently and as mixtures, as described in the following sections.

\subsection{Characterization and Classification}

All samples were oven dried at $110 \pm 5{ }^{\circ} \mathrm{C}$ until the equilibrium in the dry weight has been reached (almost 24 hrs.) so as to unify the initial testing conditions among the samples. The specific gravity $\left(\mathrm{G}_{\mathrm{S}}\right)$ of sand, MMT, and the mixtures were obtained using ASTM standard method [6], as shown in Table 1. For MMT, the liquid limit $\left(\omega_{\mathrm{L}}\right)$ was determined using 
Casagrande device in accordance with ASTM standard [7]. In contrast, an appropriate correlation reported in the literature (Eq. 1) is used to estimate the plasticity index $\left(I_{P}\right)$ for the MMT due to the practical difficulties associated with carrying out a plastic limit $\left(\omega_{\mathrm{P}}\right)$ test on highly plastic clays [8]. Furthermore, the grain size distribution of the samples was obtained by conducting mechanical sieving and hydrometer analysis in accordance with ASTM standards [9], [10], respectively, as shown in Figure 1. Moreover, the cation exchange capacity (CEC) for the MMT was determined using EPA method [11]. The characterization results of the sand and sand-MMT mixtures are presented in Table 2, while for MMT; the results are summarized in Table 3.

Table 1: Specific Gravity Results.

\begin{tabular}{|c|c|}
\hline Sample & Specific Gravity, Gs \\
\hline Sand (0\% MMT) & 2.653 \\
\hline 100\% MMT & 2.353 \\
\hline Sand + 2\% MMT & 2.647 \\
\hline Sand + 4\% MMT & 2.640 \\
\hline Sand +6\% MMT & 2.634 \\
\hline
\end{tabular}

$$
\mathrm{I}_{P}(\%)=\left[0.96 \times \omega_{L}(\%)\right]-[(0.26 \times C F(\%))+10]
$$

Where: $\mathrm{I}_{\mathrm{P}}=$ plasticity index; $\mathrm{w}_{\mathrm{L}}=$ liquid limit; $\mathrm{CF}=$ clay fraction, defined as the percentage of the particles size $<2 \mu \mathrm{m}$.

Table 2: Characterization Summary for Sand and Sand-MMT Mixtures.

\begin{tabular}{|c|c|c|c|c|c|c|c|c|c|}
\hline Sample & $\begin{array}{c}\text { Passing } \\
\text { Sieve\# 200 } \\
(\%)\end{array}$ & $\begin{array}{l}\mathrm{D}_{10}{ }^{1} \\
(\mathrm{~mm})\end{array}$ & $\begin{array}{c}\mathbf{D}_{30} \\
(\mathbf{m m})\end{array}$ & $\begin{array}{c}\mathbf{D}_{50} \\
(\mathbf{m m})\end{array}$ & $\begin{array}{c}\mathbf{D}_{60} \\
(\mathbf{m m})\end{array}$ & $\mathrm{C}_{\mathrm{C}^{2}}^{2}$ & $\mathbf{C}_{U^{3}}^{3}$ & $\begin{array}{c}\text { USCS } \\
\text { Classification } \\
{[12]}\end{array}$ & $\begin{array}{c}\text { AASHTO } \\
\text { Classification }\end{array}$ \\
\hline Sand (0\% MMT) & 0.6 & 0.105 & 0.173 & 0.248 & 0.288 & 0.99 & 2.74 & SP & A-3 (1) \\
\hline Sand $+2 \%$ MMT & 3.0 & 0.098 & 0.167 & 0.243 & 0.284 & 1.00 & 2.90 & SP & A-3 (1) \\
\hline Sand + 4\% MMT & 4.8 & 0.092 & 0.163 & 0.240 & 0.282 & 1.02 & 3.07 & SP & A-3 (1) \\
\hline Sand + 6\% MMT & 6.8 & 0.086 & 0.159 & 0.239 & 0.282 & 1.04 & 3.28 & SP-SM & A-3 (1) \\
\hline
\end{tabular}

${ }^{1}: \mathrm{D}_{\mathrm{Xx}}$ means the diameter where XX\% of particles are finer/smaller.

${ }^{2}$ : Coefficient of Curvature

3: Coefficient of Uniformity

Table 3: Characterization Summary for 100\% MMT.

\begin{tabular}{|c|c|c|c|c|c|c|c|c|c|c|}
\hline $\begin{array}{c}\text { CF } \\
(\%)\end{array}$ & $\begin{array}{c}\text { Passing } \\
\text { Sieve\# } \\
\mathbf{2 0 0} \\
(\boldsymbol{\%})\end{array}$ & $\begin{array}{c}\omega_{\mathrm{L}} \\
(\%)\end{array}$ & $\begin{array}{c}\omega_{\mathrm{P}} \\
(\%)\end{array}$ & $\begin{array}{c}\mathbf{I}_{\mathbf{P}} \\
(\boldsymbol{\%}) \\
{[8]}\end{array}$ & $\begin{array}{c}\text { USCS } \\
\text { Classification } \\
{[12]}\end{array}$ & $\begin{array}{c}\text { AASHTO } \\
\text { Classification }\end{array}$ & $\begin{array}{c}\text { Plasticity } \\
{[13]}\end{array}$ & $\begin{array}{c}\text { Activity } \\
{[14]}\end{array}$ & $\begin{array}{c}\text { PEC } \\
\text { Expansiveness } \\
{[15]}\end{array}$ & $\begin{array}{c}\text { Na/ } \\
\mathbf{1 0 0} \\
\mathbf{1 0 m}) \\
{[11]}\end{array}$ \\
\hline 98.3 & 100 & 434.4 & 52.9 & 381.5 & $\mathrm{CH}$ & A-7-5 (457) & $\begin{array}{c}\text { Very } \\
\text { High }\end{array}$ & $\begin{array}{c}\text { Active } \\
\text { Clay }\end{array}$ & Very High & 90 \\
\hline
\end{tabular}




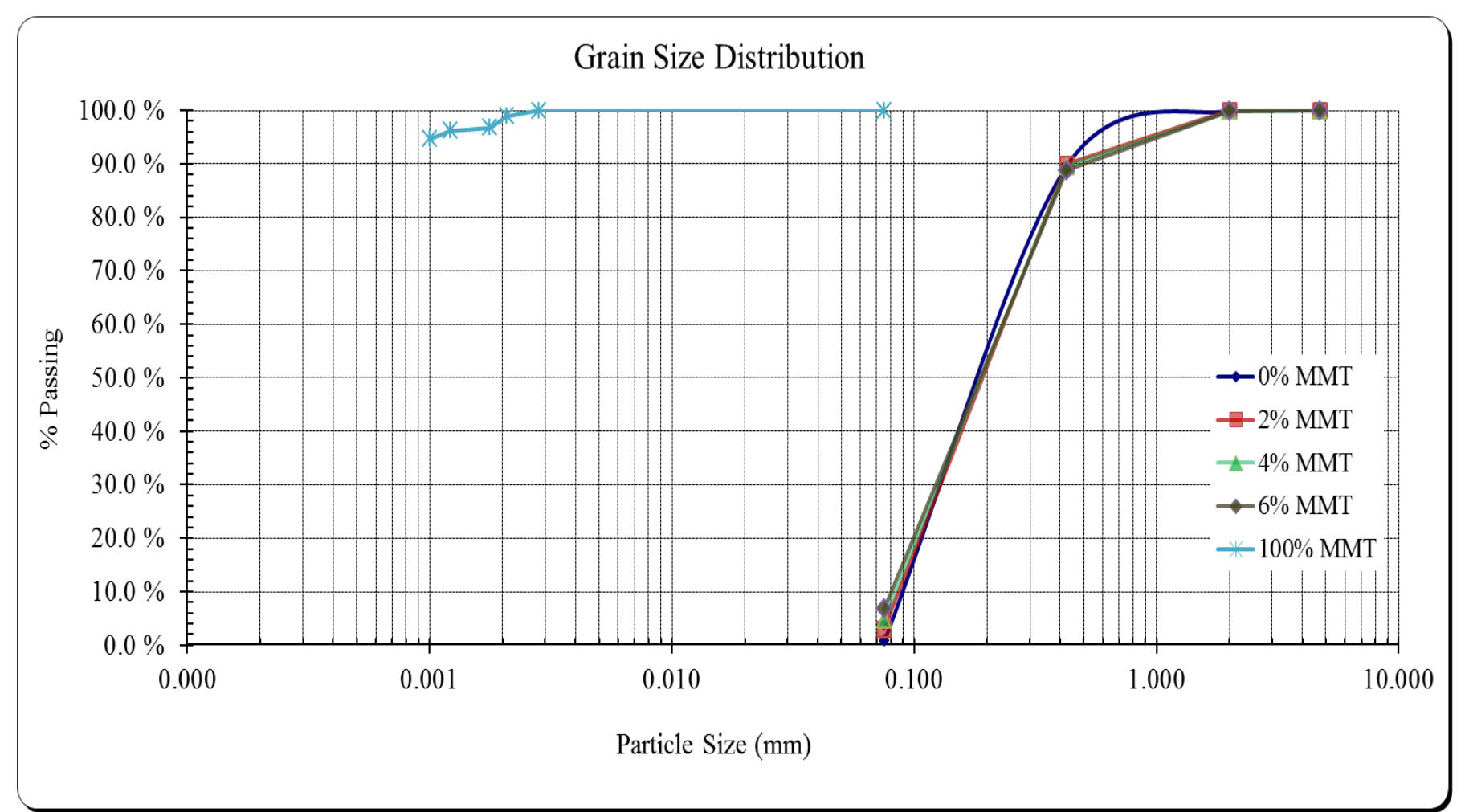

Fig. 1: Grain Size Distribution for MMT, Sand, and Sand-MMT Mixtures.

Additionally, the composition of sand and MMT was qualitatively studied using X-ray diffraction method (XRD). The XRD was used to identify the materials because each material has a characteristic wavelength due to the diffraction based on Bragg 's law [16]. The diffractometer Rigaku MiniFlex $I^{\circledR}{ }^{\circledR}$ with a (Copper K- $\alpha$ ) X-ray energy was used for this purpose, as depicted in Figures 2(a) and 2(b). For sand, as shown in Figure 2(a), the peaks indicate the presence of quartz minerals and a minority of calcite. While for MMT, as shown in Figure 2(b), the peaks are in good agreements with a typical MMT minerals associated with some impurities. 

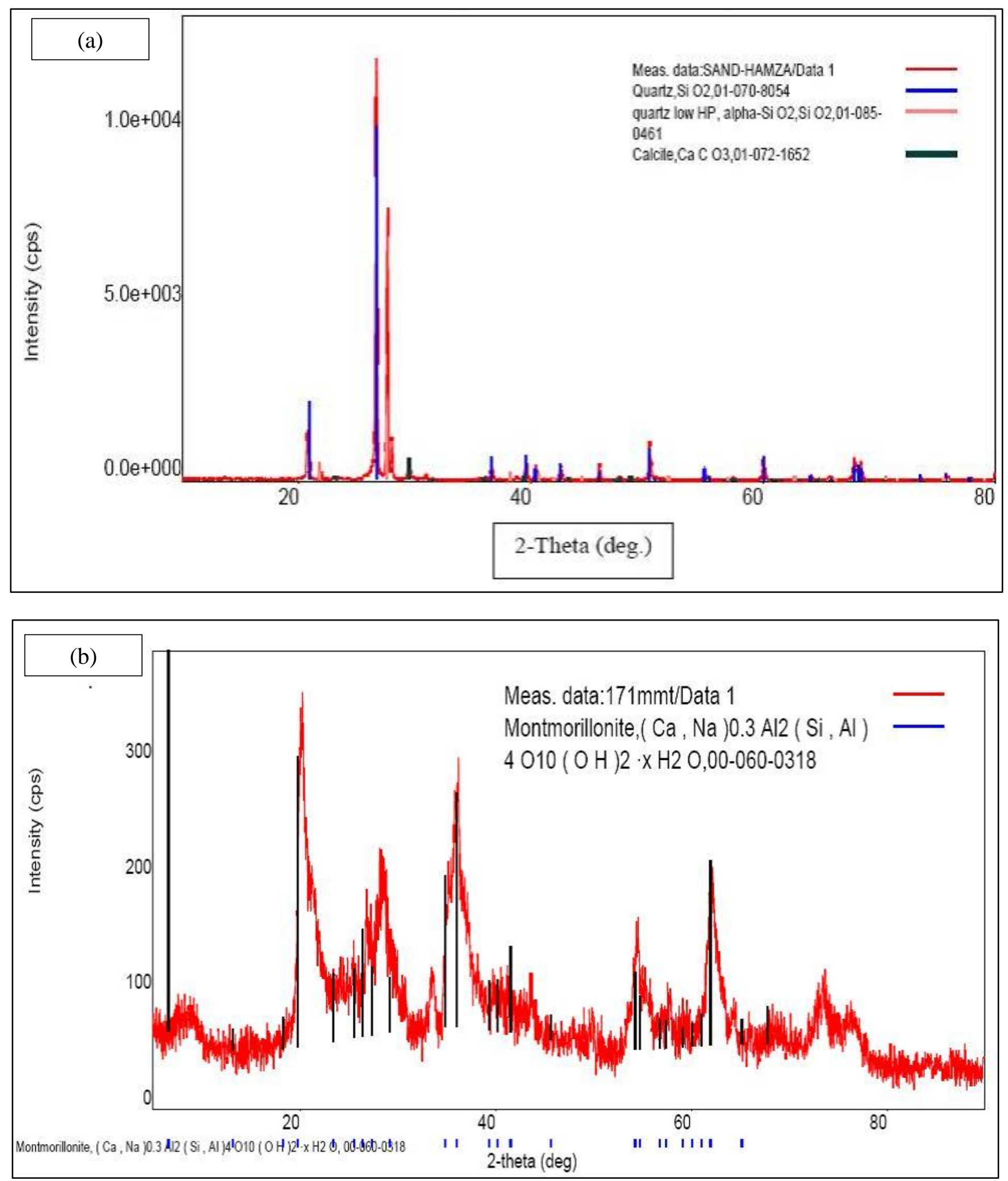

Fig. 2: XRD Results for (a) Sand and (b) MMT. 
Also, the scanning electron microscopy (SEM) technique was used to obtain high-quality images for sand and MMT that show the particles size, shape, and surface conditions. Manfred von Ardenne invented the first SEM in 1937 [17]. The SEM produces material images of high resolution and magnification (more than $1 \mathrm{~nm}$ ) by scanning the surface of the material using a focused beam of electrons, and it can detect distances less than $100 \AA$ [18]. The instrument used for this study is Tescan Lyra- $3^{\circledR}$; a field emission dual beam (focused ion beam) electron microscope (FE-SEM) which uses gallium ions as a source of the focused electrons, with a magnification up to 1,000,000X. The soil samples were coated with gold for electrical charges insulation to enhance the image resolution, as shown in Figures 3(a) and 3(b) for sand and MMT, respectively.

The SEM image shown in Figure 3(a) was utilized to determine the particles sizes and shapes using digital image analysis and processing. An open source package, namely Image $J^{\circledR}$, developed by the National Institutes of Health in the USA, is used for this purpose. The 3D, and then 2D, images if analyzed and processed correctly, would yield the most accurate particles size and shape as reported by [19]-[21]. The ImageJ ${ }^{\mathbb{B}}$ built-in shape descriptors of the particles were used in this study; which are the projected area, projected perimeter, circularity, aspect ratio, roundness, and solidity as summarized in Table 4. However, to confirm the image processing results, the projected perimeter was converted to an equivalent diameter, and then the grain size distribution was obtained. The latter has been found to be in good agreement with the mechanical sieve results, as shown in Figure 4. The processed SEM image is depicted in Figure 5. It is worthy to be noted that Figure 3(b) shows an agglomerated particles image for MMT which may not represent the actual size or shape of the particles and, therefore, this SEM image for MMT was not processed. In the conventional SEM, it is quite difficult to obtain a dispersed particles image, but this might be possible through an environmental SEM.
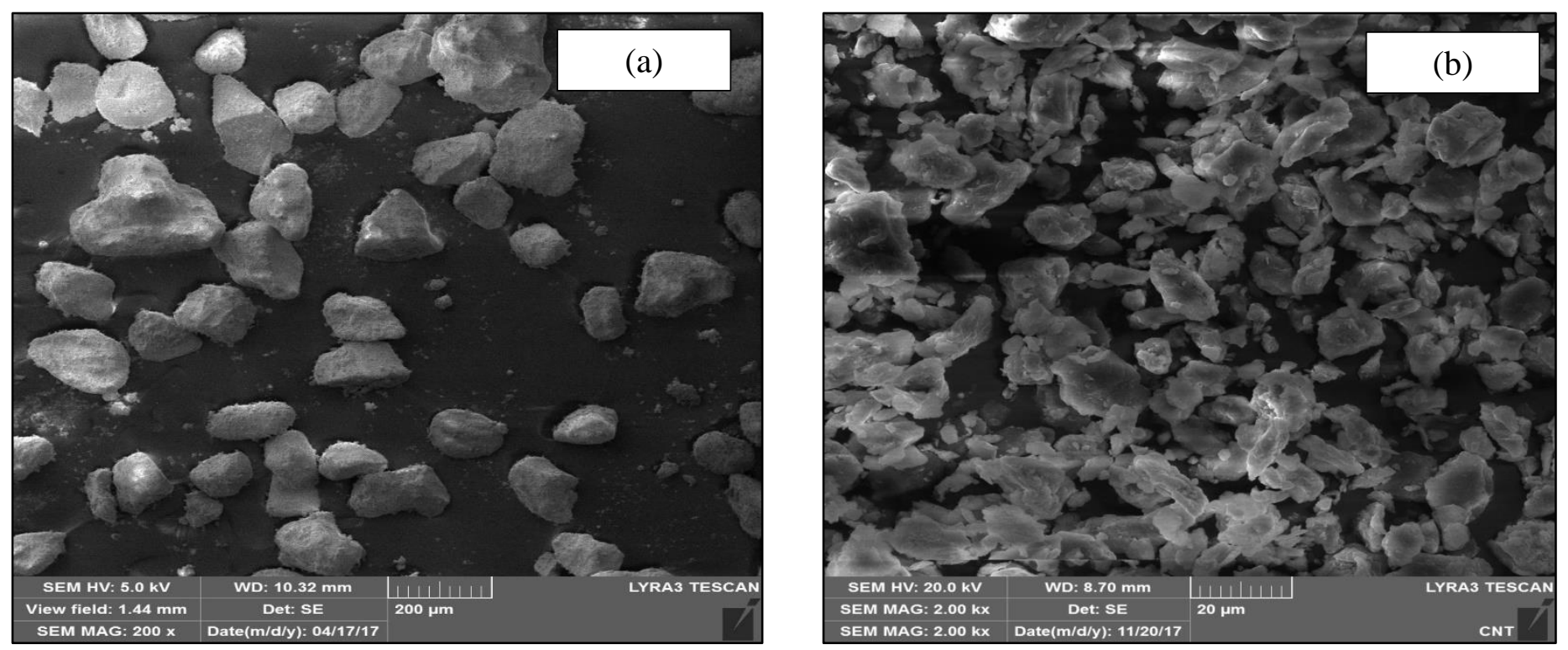

Fig. 3: SEM Images for (a) Sand and (b) MMT. 


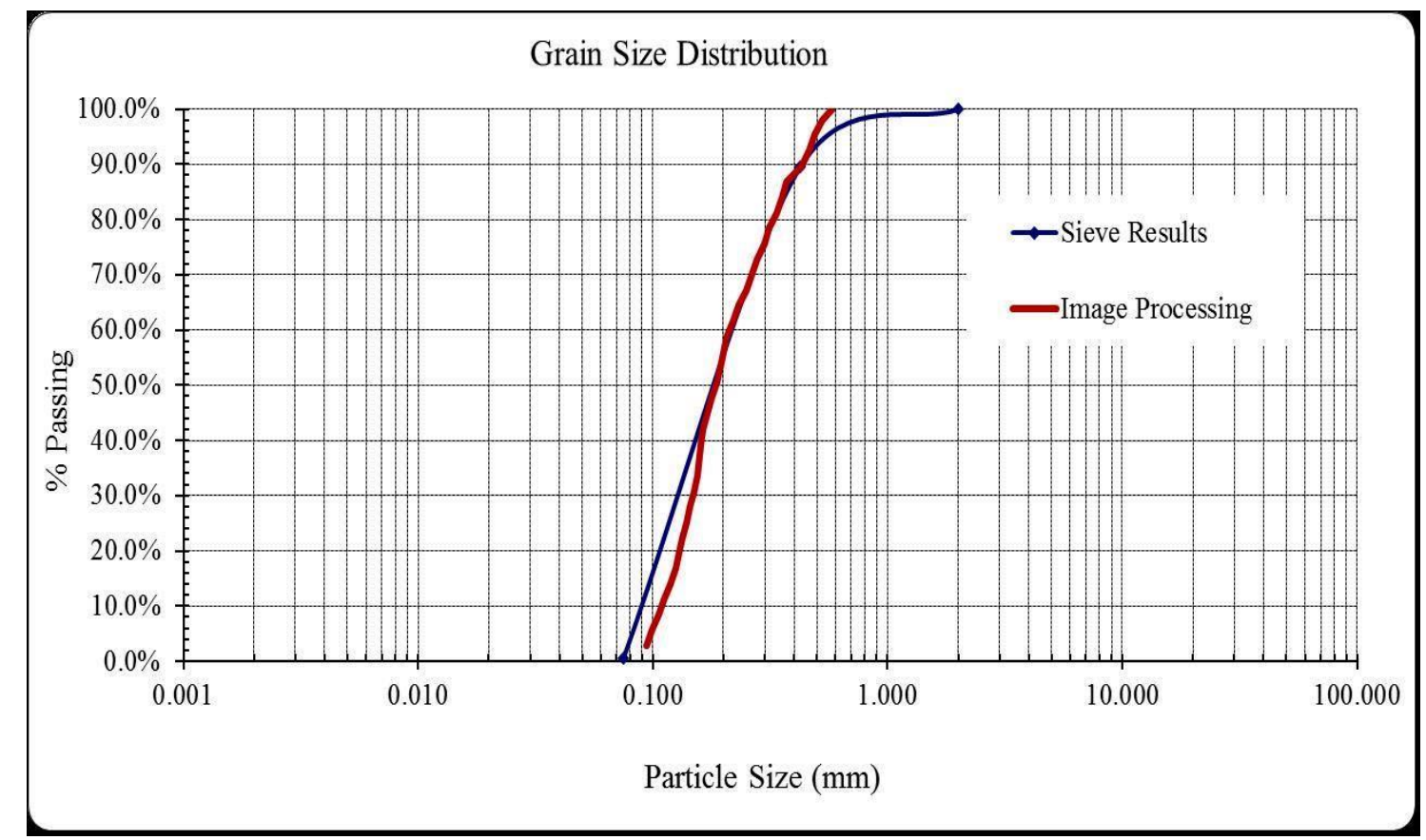

Fig. 4: Grain Size Distribution for Sand (0\% MMT) by Sieve and Image Processing Methods.

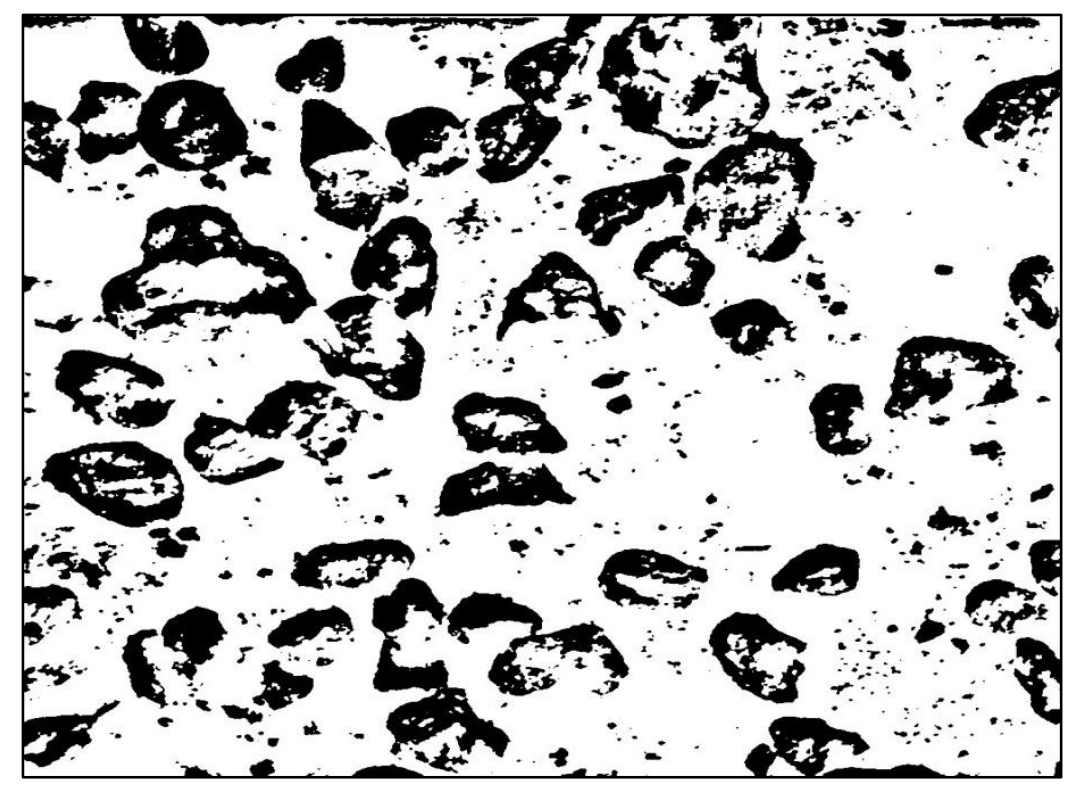

Fig. 5: Analysis and Processing of SEM Image for Sand (0\% MMT).

Table 4: Image Processing Summary for Sand (0\% MMT).

\begin{tabular}{|c|c|c|c|c|c|c|}
\hline $\begin{array}{c}\text { Number } \\
\text { of } \\
\text { Particles }\end{array}$ & $\begin{array}{c}\text { Average Projected } \\
\text { Area }\left(\mathbf{m m}^{\mathbf{2}}\right)\end{array}$ & $\begin{array}{c}\text { Average Projected } \\
\text { Perimeter }(\mathbf{m m})\end{array}$ & $\begin{array}{c}\text { Average } \\
\text { Circularity }\end{array}$ & $\begin{array}{c}\text { Average Aspect } \\
\text { Ratio }\end{array}$ & $\begin{array}{c}\text { Average } \\
\text { Roundness }\end{array}$ & $\begin{array}{c}\text { Average } \\
\text { Solidity }\end{array}$ \\
\hline 36 & $0.00992 \pm 0.00666$ & $0.788 \pm 0.446$ & $0.255 \pm 0.142$ & $2.176 \pm 1.904$ & $0.579 \pm 0.196$ & $0.654 \pm 0.113$ \\
\hline
\end{tabular}


Finally, the maximum dry density (MDD) and optimum moisture content (OMC) for the sand-MMT mixtures were determined by conducting the modified Proctor tests in accordance with ASTM standard [22]. The three sand-MMT mixtures were prepared at $95 \%$ of MDD on both wet and dry sides of optimum for each mixture for the suction measurements. The compaction curves for the three mixtures are shown in Figures 6(a), 6(b), and 6(c), respectively. The summary of the compaction tests is shown in Table 5.
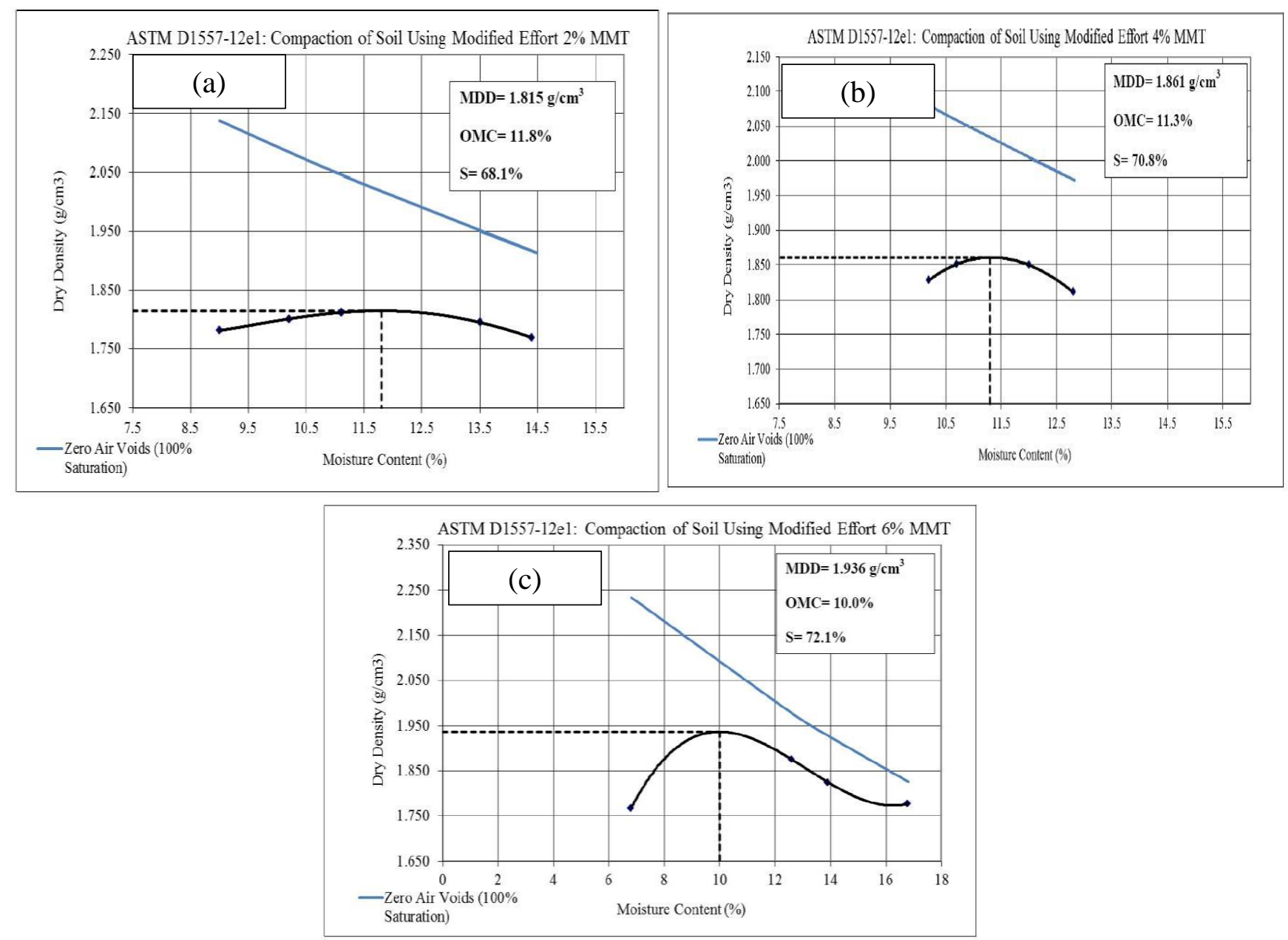

Fig. 6: Modified Compaction Curves for Sand + (a) 2\% MMT, (b) 4\% MMT and (c) 6\% MMT.

Table 5: Summary of Compaction Tests for Sand-MMT Mixtures.

\begin{tabular}{|c|c|c|c|c|c|c|}
\hline Sample & $\begin{array}{l}\text { 95\% MDD } \\
\text { (g/cc) }\end{array}$ & $\begin{array}{l}\text { Dry/Wet of } \\
\text { Optimum }\end{array}$ & $\begin{array}{c}\text { OMC } \\
(\%)\end{array}$ & $\mathrm{S}(\%)$ & $\begin{array}{c}\text { Volumetric }^{*} \\
\text { Water Content } \\
\left(\mathbf{m}^{3} / \mathbf{m}^{3}\right) \\
\end{array}$ & $\begin{array}{c}\text { Initial } \\
\text { Void } \\
\text { Ratio, } \mathbf{e}_{\mathbf{0}}\end{array}$ \\
\hline Sand + 2\% MMT & 1.724 & \multirow{3}{*}{ Dry } & 7.7 & 38.1 & 0.133 & 0.535 \\
\hline Sand $+4 \%$ MMT & 1.768 & & 9.5 & 50.9 & 0.168 & 0.493 \\
\hline Sand $+6 \%$ MMT & 1.839 & & 7.5 & 45.7 & 0.138 & 0.432 \\
\hline Sand $+2 \%$ MMT & 1.724 & \multirow{3}{*}{ Wet } & 15.6 & 77.1 & 0.269 & 0.535 \\
\hline Sand $+4 \%$ MMT & 1.768 & & 13.4 & 71.7 & 0.237 & 0.493 \\
\hline Sand $+6 \%$ MMT & 1.839 & & 13.5 & 82.3 & 0.248 & 0.432 \\
\hline
\end{tabular}

"The volumetric water content is determined by multiplying the dry density $(\mathrm{g} / \mathrm{cc})$ and gravimetric water content (as a fraction) 


\subsection{Suction Measurements by Filter Paper Method (FPM)}

The FPM is considered as the only method which can provide both total and matric suction [4]. However, and as stated earlier, the matric suction has a more significant role in geotechnical engineering applications than the total suction. The FPM is an economical method and more applicable for a matric suction range from 0.01 to $100 \mathrm{MPa}$, while for total suction, the FPM usually provides smaller values compared with the total suction measured from the other methods [2], [23]. The "chemical potential" term is sometimes used instead of "suction," and indicates the energy status of the soil water.

Six soil samples were prepared (as shown previously in Table 5) for the suction measurements. The measurements were conducted in accordance with ASTM standard [5] using (Whatman No. 42) ash-free filter papers. The filter papers were oven dried for at least 16 hours, because the calibration curves reported in the standard and literature, which are used to obtain both the total and matric suctions against the filter moisture content, are valid for the initially dried filter papers [24]. The effects and the hysteresis between the initially dry and initially wet filter papers have been recently discussed by Leong et al. [23].

However, each of the prepared soil samples was, then, cut into two halves and an inner filter paper was placed between two outer filter papers. The former has a diameter of 3 to $4 \mathrm{~mm}$ smaller. Then, the inner and outer filter papers were placed in between the two halves in direct contact with the soil sample. To that end, the inner filter paper was used to determine the matric suction of the soil. If a sample is not sufficiently moist, the direct contact between the filter papers and the sample might not be achieved. Thereafter, the soil sample was placed into a jar covering at least $75 \%$ of its volume to maintain the equilibrium time as minimum as possible. Then, a sharp-edges O-ring was positioned atop of the soil sample in the jar, and two filter papers were placed on the ring with no direct contact between the filter papers and the soil in order to measure the soil total suction. The filter papers should not be touched with bare hands, but with tweezers and gloves, and nothing should be written on them.

As per the ASTM standard, the equilibrium time adopted in this study was seven days, but for a small range of suction $(<100 \mathrm{kPa})$, it may require more than 30 days to reach the equilibrium [23]. The jars were sealed with electrical duct tape and stored in a temperature-controlled container. After the equilibrium time was reached, three cans with their lids were prepared for each jar, and their cold weights $\left(\mathrm{T}_{\mathrm{C}}\right)$ were recorded using a balance of $0.0001 \mathrm{~g}$ sensitivity. Once the jar was opened, the upper filter paper was placed into the can and closed by the lid and weighted in the balance $\left(\mathrm{M}_{1}\right)$ within 5 seconds to prevent the moisture content loss and/or changes. The same was done for the lower filter paper. The upper half of the soil was then extracted, and the outer filter papers were held by the tweezer to extract the inner filter paper which was placed in a can and weighted within 5 seconds. The outer filter papers were then disposed of. They should not be used again for any reason. After that, the cans were kept partially closed/sealed in the oven for 2 hours, and completely sealed for 15 minutes. Subsequently, the cans were extracted from the oven and placed on an aluminum block to cool them down for 20 seconds; and their weights were recorded accordingly $\left(\mathrm{M}_{2}\right)$. Finally, the filter papers were disposed of, and the hot weights of the cans and lids were recorded $\left(\mathrm{T}_{\mathrm{H}}\right)$. The moisture content of each filter paper $\left(\omega_{\mathrm{F}}\right)$ was then calculated from Eq. 2.

$$
\omega_{F}(\%)=\frac{\left(M_{1}-M_{2}+T_{H}-T_{C}\right) \times 100}{M_{2}-T_{H}}
$$

Using the filter paper moisture content and the calibration curve, the total and matric suction values could be obtained. According to Suits et al. [24], the best fit models using (Whatman No. 42) filter papers calibration curves for both matric and total suction are given in Eqs. 3(a and b) and 4, respectively. For total suction ( $\psi$ ), the average value obtained from Eq. 4 for the upper and lower filter papers should be taken as the total suction if the difference between the two values does not exceed $(0.5 \log \mathrm{kPa})$. Otherwise, the experiment should be repeated. The results of the FPM experiments are summarized in Table 6, and Figure 7. Further details about the calibration curves are given by Bicalho et al. [25].

$$
\text { For } \omega_{F} \geq 47 \%: \quad \log \left[\mathrm{u}_{a}-\mathrm{u}_{w}(k P a)\right]=2.909-\left[0.0229 \times \omega_{F}(\%)\right]
$$




$$
\begin{aligned}
& \text { For } \omega_{F}<47 \%: \quad \log \left[\mathrm{u}_{a}-\mathrm{u}_{w}(k P a)\right]=4.945-\left[0.0673 \times \omega_{F}(\%)\right] \\
& \psi(\mathrm{kPa})=56180 \times\left[\left(\frac{37}{\omega_{F}(\%)}\right)^{0.44}-1\right]^{2.361}
\end{aligned}
$$

\begin{tabular}{|c|c|c|c|c|c|c|}
\hline Sample & $\begin{array}{l}\text { 95\% MDD } \\
\text { (g/cc) }\end{array}$ & $\begin{array}{c}\text { Dry/Wet of } \\
\text { Optimum }\end{array}$ & $\mathrm{S}(\%)$ & $\begin{array}{c}\text { Initial Void } \\
\text { Ratio, } \mathbf{e}_{0}\end{array}$ & $\begin{array}{c}\text { Average } \psi \\
\text { (kPa) }\end{array}$ & $\begin{array}{c}\mathbf{u}_{\mathbf{a}}-\mathbf{u}_{\mathbf{w}} \\
(\mathbf{k P a})\end{array}$ \\
\hline Sand $+2 \%$ MMT & 1.724 & \multirow{3}{*}{ Dry } & 38.1 & 0.535 & 1366.0 & 5.3 \\
\hline Sand $+4 \%$ MMT & 1.768 & & 50.9 & 0.493 & 1354.1 & 16.4 \\
\hline Sand $+6 \%$ MMT & 1.839 & & 45.7 & 0.432 & 6293.6 & 863.6 \\
\hline Sand $+2 \%$ MMT & 1.724 & \multirow{3}{*}{ Wet } & 77.1 & 0.535 & 1151.2 & 2.5 \\
\hline Sand + 4\% MMT & 1.768 & & 71.7 & 0.493 & 1907.8 & 4.6 \\
\hline Sand + 6\% MMT & 1.839 & & 82.3 & 0.432 & 4906.3 & 14.0 \\
\hline
\end{tabular}

Table 6: Summary of FPM Experiments.

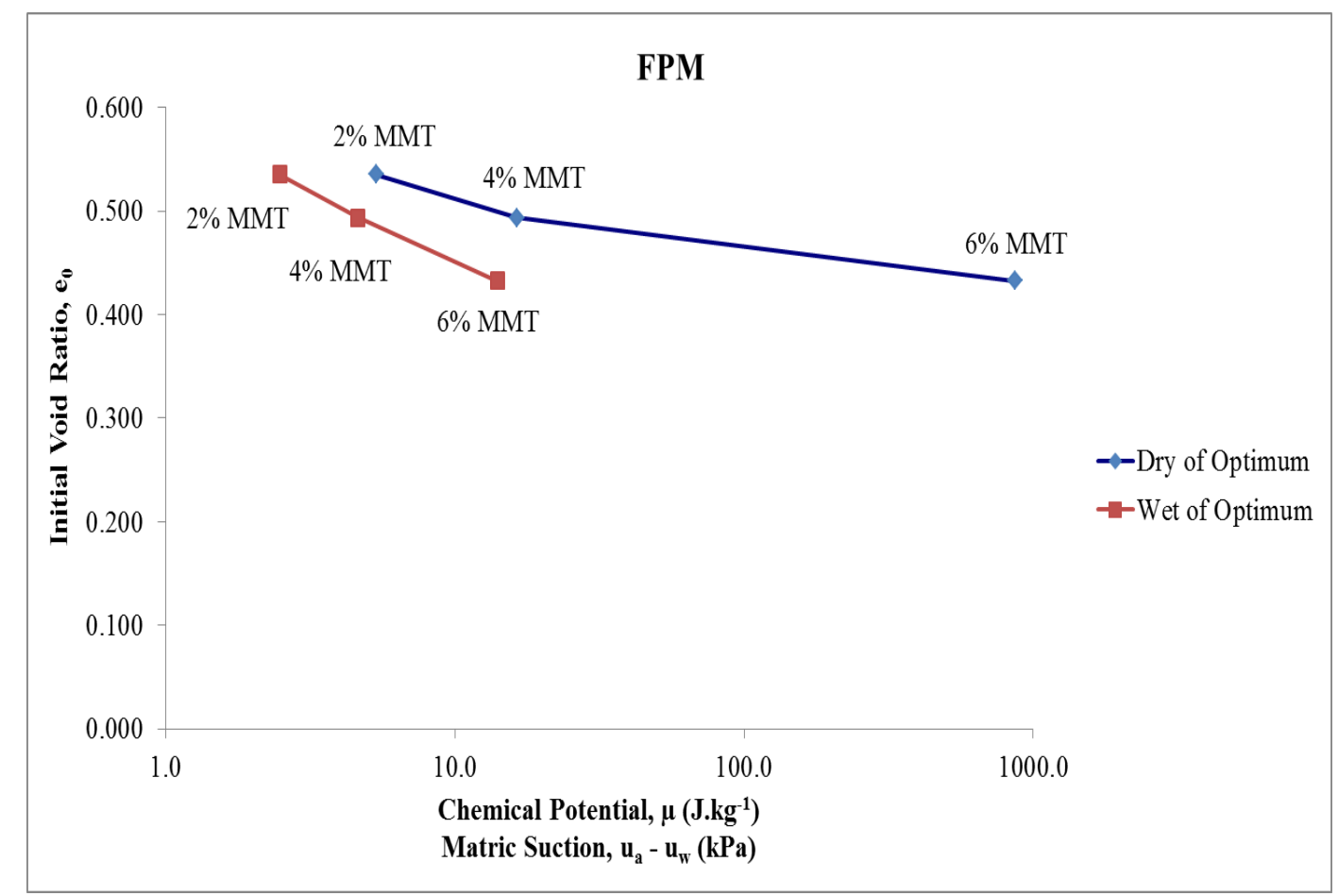

Fig. 7: Matric Suction Results Using FPM against Void Ratio.

\section{Estimation of SWCC}

The SWCC of a soil requires the complete profile of suction vs. saturation degree or the water content, which requires a lot of time and efforts to attain, therefore, obtaining the complete SWCC experimentally is not viable in many cases. Several studies reported in the literature provided mathematical expressions to empirically describe and estimate the SWCC [26], [27]. However, recent studies have more concerned with the validity of the provided models and aim to suggest the best-fit parameters obtained from other soil properties, such as grain size distribution, the percentage of MMT, Atterberg limits, among others [28]-[31]. The model provided by Fredlund and Xing [27] as shown in Eq. 5, is found to be the most suitable for different types of soils and various ranges of matric suction [30], [32]. Chin et al. [30] provided reliable and simplified models for fitting parameters $\mathrm{a}, \mathrm{n}$, and $\mathrm{m}$ based on the $\mathrm{D}_{50}$ and percentage of passing sieve No. 200, as illustrated in Eqs. 6(a, b, c and d) and 7(a, b, c and d). 


$$
\mathrm{S}=\left[1-\frac{\ln \left(1+\frac{u_{a}-u_{w}}{\left(u_{a}-u_{w}\right)_{r}}\right)}{\ln \left(1+\frac{10^{6}}{\left(u_{a}-u_{w}\right)_{r}}\right)}\right] \times \frac{1}{\left[\ln \left(\exp (1)+\left(\frac{u_{a}-u_{w}}{a}\right)^{n}\right)\right]^{m}}
$$

Where: $\mathrm{S}=$ saturation level as fraction; $\left(\mathrm{u}_{\mathrm{a}}-\mathrm{u}_{\mathrm{w}}\right)=$ matric suction in $\mathrm{kPa} ;\left(\mathrm{u}_{\mathrm{a}}-\mathrm{u}_{\mathrm{w}}\right)_{\mathrm{r}}=$ reference suction in $\mathrm{kPa} ; \mathrm{a}, \mathrm{n} \& \mathrm{~m}=$ fitting paramters.

If the percent passing sieve No. $200<30 \%$ :

$$
\begin{gathered}
\mathrm{a}=0.53 \times\left(D_{50}(\mathrm{~mm})\right)^{-0.96} \\
\mathrm{n}=x \\
\mathrm{~m}=1.13-(0.23 \times \ln (x)) \\
\left(u_{a}-u_{w}\right)_{r}(\mathrm{kPa})=100
\end{gathered}
$$

If the percent passing sieve No. $200 \geq 30 \%$ :

$$
\begin{gathered}
\mathrm{a}=722-(2.4 \times x) \\
\mathrm{n}=0.07 \times(x)^{0.4} \\
\mathrm{~m}=0.015 \times(x)^{0.7} \\
\left(u_{a}-u_{w}\right)_{r}(\mathrm{kPa})=914 \times \exp (-0.002 \times(x))
\end{gathered}
$$

The parameter (x), which is shown in Eqs. 6 and 7 for Chin et al. method [30], is obtained by trial and error until the SWCC passes through the measured point. Considering the nature of the soil within this study, Eq. 6 was utilized to estimate the SWCC's. Although this method has been used to estimate the SWCC from usually a single measurement point, in this study, two points (on dry and wet sides of optimum) were measured per each sample to validate the precision and applicability of the method to fit the experimental data. For the three sand-MMT mixtures (2\%, 4\%, and 6\% MMT), with two points measured for each mixture, the fitting parameters are summarized in Table 7 . The estimated SWCC for the mixtures passes through all of the experimental data (except for the 4\% MMT where one of the two points shifted slightly from the SWCC), as shown in Figure 8. The air-entry suction values (AEV) are also shown in Figure 8.

Table 7: Summary of Fitting Parameters for Fredlund and Xing [26] Eq. 5.

\begin{tabular}{|c|c|c|c|c|c|}
\hline Sample & $\begin{array}{c}\text { 95\% MDD } \\
(\mathbf{g} / \mathbf{c c})\end{array}$ & $\mathbf{G}_{\mathbf{S}}$ & $\mathbf{a}$ & $\mathbf{n}$ & $\mathbf{m}$ \\
\hline Sand + 2\% MMT & 1.724 & 2.647 & 2.06 & 3.00 & 0.88 \\
\hline Sand + 4\% MMT & 1.768 & 2.640 & 2.09 & 0.44 & 1.32 \\
\hline Sand +6\% MMT & 1.839 & 2.634 & 2.09 & 96.65 & 0.08 \\
\hline
\end{tabular}




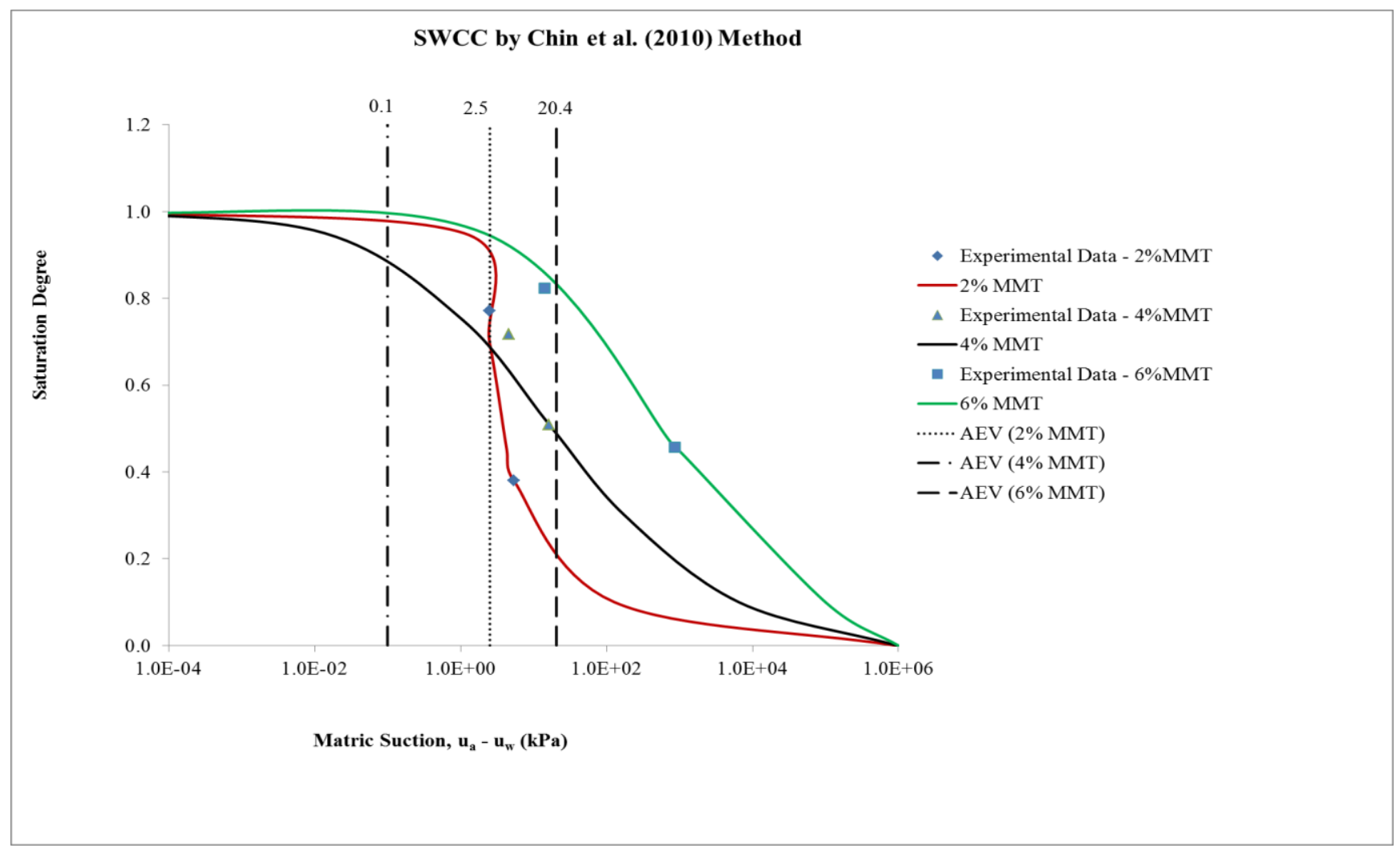

Fig. 8: Estimated SWCC's by Chin et al. (2010) Method.

For the fitting parameter ( $\mathrm{n}$ or $\mathrm{x}$ ), it was noticed that it has a clear correlation with both the specific gravity and the 95\% MDD (the experimental dry density of the samples). Therefore, a stepwise multiple linear regression analysis was

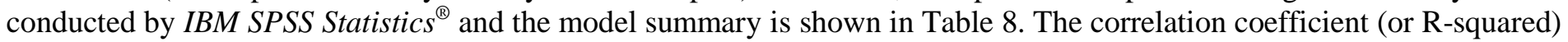
of 1.0, as shown in Figure 9, indicates a powerful correlation between the regressors and the dependent variable (parameter n). Using Minitab ${ }^{\circledR}$, the normal probability plot of the parameter (n) and the surface plot of the statistical model are generated, which are shown in Figures 10(a) and 10(b), respectively. At a confidence level of 95\% (i.e., level of significance of 0.05), the probability of 0.09 as shown in Figure 10(a) indicates that the parameter (n) follows a normal distribution. Therefore, the proposed parametric regression model is applicable. The model is shown in Eq. 8. However, it should be noted that the model is valid only for the tested materials and under the same conditions, in which the samples were prepared, and the experiment was conducted.

Table 8: Summary of Fitting Parameter (n) Regression Model.

\begin{tabular}{|c|c|c|c|c|c|}
\hline R-Squared & $\begin{array}{c}\text { Adjusted R- } \\
\text { Squared }\end{array}$ & $\begin{array}{c}\text { Durbin } \\
\text { Watson }\end{array}$ & $\begin{array}{c}\text { Regression Sum } \\
\text { of Squares }\end{array}$ & $\begin{array}{c}\text { Residual Sum } \\
\text { of Squares }\end{array}$ & $\begin{array}{c}\text { Regression } \\
\text { Mean of Square }\end{array}$ \\
\hline 1.000 & 1.000 & 0.001 & 12022.160 & 0.000 & 6011.080 \\
\hline
\end{tabular}

Where: $\mathrm{n}=$ fitting parameter; $\mathrm{MDD}=$ maximum dry density at which the samples were prepared; $\mathrm{G}_{\mathrm{S}}=$ specific gravity 


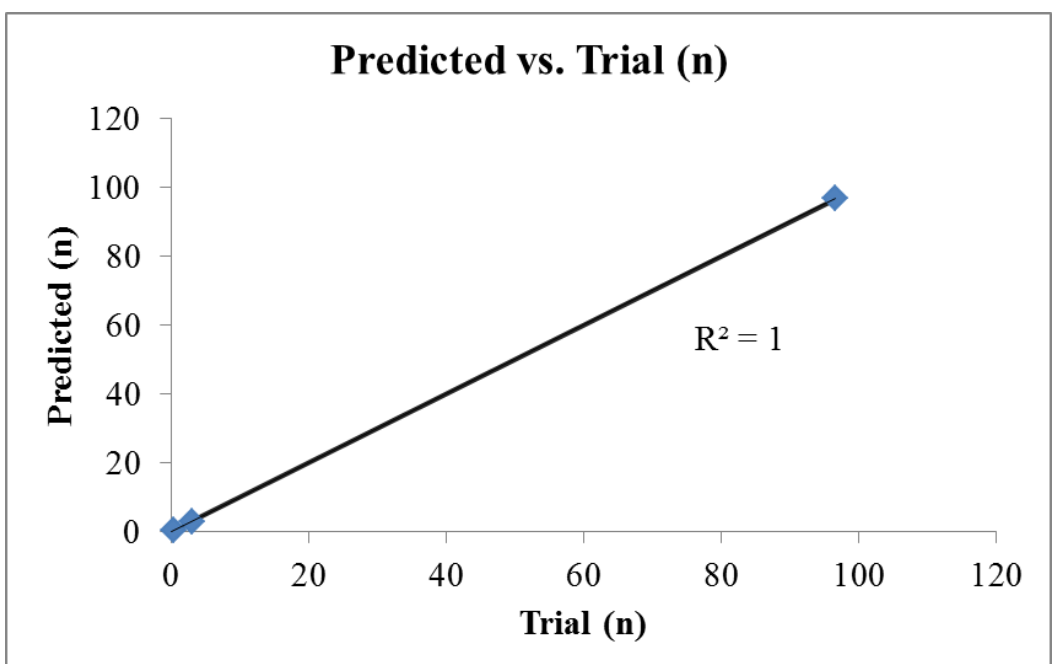

Fig. 9: Correlation Coefficient of Fitting Parameter (n) Regression Model.

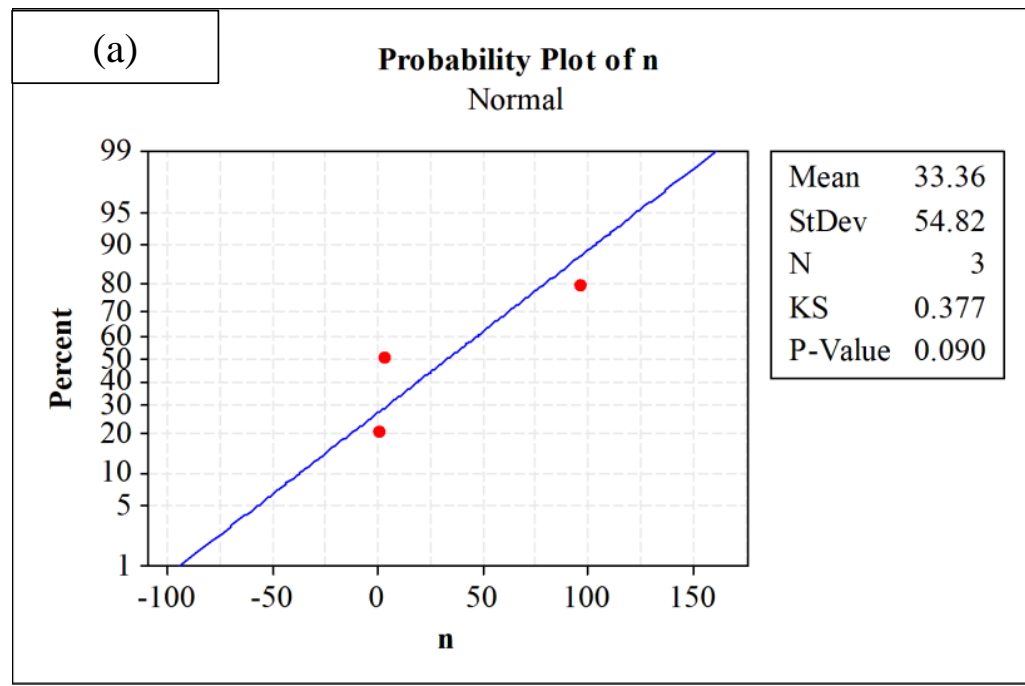

(b)

Fitting Parameter (n) Model

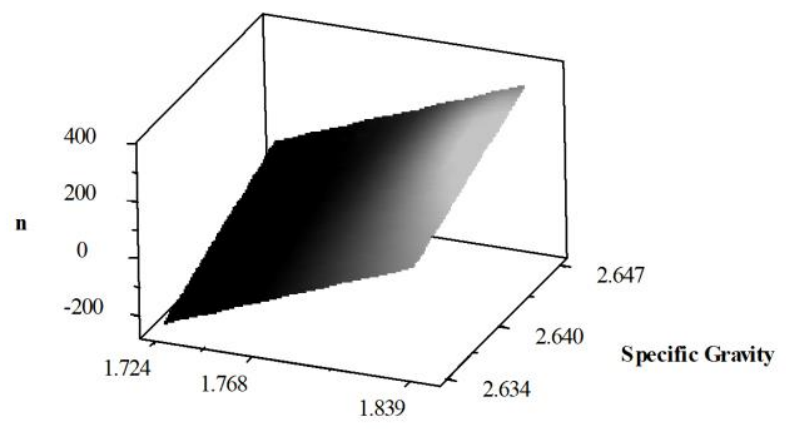

Experimental Dry Density (g/cc)

Fig. 10: Fitting Parameter (n): (a) Normal Probability Plot and (b) Regression Model Surface Plot. 


\section{Application in the Design of Shallow Foundations}

Due to the sophistication and high cost associated with testing unsaturated soils, the concept of unsaturated soil mechanics and matric suction is not fully utilized practically by the geotechnical profession in many places. However, FPM accompanied by an estimated SWCC (from FPM) can facilitate and enhance the practicality of this concept. One of the applications in which SWCC is involved, is the design of shallow foundations because the majority of the geotechnical projects in arid and semi-arid areas are taking place in the unsaturated zones of the soil [33]. The research being carried out on this topic is highly needed. Recently published work has been reported by [34]-[38]. The effective stresses in the unsaturated soil ( $\left.\sigma^{\prime}\right)$ can be expressed in terms of the matric suction and net normal stresses $\left(\sigma-\mathbf{u}_{a}\right)$, as shown in Eq. 9 [39]. However, Vanapalli and Mohamed [36] provided a simplified approach to calculate the ultimate bearing capacity for shallow foundations in saturated and unsaturated sandy soils, using a form of Terzaghi's bearing capacity equation [40] for saturated soil combined with matric suction and effective stresses concepts on unsaturated soils. Their proposed equations, as shown in Eqs. 10(a) to 10(j), were based on lab model of a shallow foundation. The authors investigated the effects of matric suction, overburden pressure, and the dilatancy angle.

$$
\begin{aligned}
& 6^{\prime}=\left(6-u_{a}\right)+\left[\left(\frac{\left(u_{a}-u_{w}\right)}{\mathrm{AEV}}\right)^{-0.55} \times\left(u_{a}-u_{w}\right)\right] \\
& \mathrm{q}_{u}(\mathrm{kPa})=\left[c^{\prime}+\left(A E V \times\left(\tan ^{\phi^{\prime}}-S^{\psi_{B C}} \tan ^{\phi^{\prime}}\right)\right)+\left(\left(u_{a}-u_{w}\right)_{a v g} S^{\left.\psi_{B C} \tan ^{\phi^{\prime}}\right)}\right)\right] N_{C} S_{C} d_{C} \\
& +\gamma D_{f} N_{q} s_{q} d_{q}+0.5 \gamma B N_{\gamma} s_{\gamma} \\
& N_{q}=\frac{e^{2\left(0.75 \pi-\frac{\phi^{\prime} \times \pi}{180}\right) \tan ^{\phi^{\prime}}}}{2 \times \cos ^{2}\left(45+\frac{\phi^{\prime}}{2}\right)} \\
& N_{c}=\left(N_{q}-1\right) \cot ^{\phi^{\prime}} \\
& \psi_{B C}=1.0+\left(0.34 \times I_{P}(\%)\right)-\left(0.0031 \times I_{P}(\%)\right) \\
& s_{C}=1.0+\frac{N_{q} \times B}{N_{C} \times L}, \quad=1.0 \text { for strip footing } \\
& d_{C}=1.0+0.4 k \\
& \mathrm{k} \text { (radians): for }\left(\frac{D_{f}}{B} \leq 1\right)=\frac{D_{f}}{B}, \text { for }\left(\frac{D_{f}}{B}>1\right)=\tan ^{-1}\left(\frac{D_{f}}{B}\right) \\
& s_{q}=1.0+\frac{B \times \tan ^{\phi \prime}}{L} \\
& d_{q}=1.0+2 \tan ^{\phi^{\prime}}\left(1-\sin ^{\phi^{\prime}}\right)^{2} k \\
& s_{\mathrm{\gamma}}=1.0-\frac{0.4 \times B}{L} \geq 0.6
\end{aligned}
$$

Where: $\mathrm{q}_{\mathrm{u}}=$ ultimate bearing capacity; $\mathrm{c}^{\prime}=$ effective cohesion $(\mathrm{kPa}) ; \Phi^{\prime}=$ effective friction angle (degree); $\mathrm{S}=$ saturation degree $(\%) ;\left(\mathrm{u}_{\mathrm{a}}-\mathrm{u}_{\mathrm{w}}\right)_{\mathrm{avg}}=$ average matric suction value defined by Vanapalli and Mohamed [36] (kPa); $\mathrm{V}=$ unit weight 
$\left(\mathrm{kN} / \mathrm{m}^{3}\right) ; \mathrm{D}_{\mathrm{f}}=$ depth of foundation $(\mathrm{m}) ; \mathrm{B}$ : width of foundation $(\mathrm{m}) ; \mathrm{N}_{\mathrm{\gamma}}=$ bearing capacity factor obtained from Kumbhojkar tables [41]. Furthermore, Vanapalli and Mohamed [36] provided new correlations for the modulus of elasticity $\left(E_{S}\right)$ with the relative density $\left(\mathrm{D}_{\mathrm{r}}\right)$ and cone tip resistance in CPT $\left(\mathrm{q}_{\mathrm{c}}\right)$ for both saturated and unsaturated soils, as shown in Eqs. 11(a) to 11(e). The $\left(\mathrm{E}_{\mathrm{S}}\right)$ can then be used in Schmertmann settlement equations [42] to determine the immediate settlement of the foundation. It has been noticed that the calculated bearing capacity values were underestimated for both saturated and unsaturated soils, especially for surface footings. The ultimate bearing capacity increased linearly with the matric suction up to AEV. Then, a non-linear increment occurred until the residual saturation zone, at which the bearing capacity decreased. While for the settlement, their proposed correlations proved a good agreement between the calculated and measured settlement values.

$$
\begin{aligned}
& \text { For saturated soils: } E_{S}(k P a)=\left[1.5 \times\left(\left(\frac{D_{r}(\%)}{100}\right)^{2}+3\right)\right] \times q_{c}(k P a) \\
& \text { For unsaturated soils: } E_{S}(k P a)=f_{2} \times q_{c}(k P a) \\
& \text { For } D_{r}<50 \%: f_{2}=\left[1.2 \times\left(\left(\frac{D_{r}(\%)}{100}\right)^{2}+3.75\right)\right] \\
& \text { For } D_{r} \geq 50 \%: f_{2}=\left[1.7 \times\left(\left(\frac{D_{r}(\%)}{100}\right)^{2}+3.75\right)\right]
\end{aligned}
$$

Where: $E_{\mathrm{s}}=$ elastic modulus; $\mathrm{D}_{\mathrm{r}}=$ relative density; $\mathrm{q}_{\mathrm{c}}=$ cone tip resistance; $\mathrm{f}_{2}=$ fitting parameter.

\section{Conclusions and Recommendations for Future Work}

Based on the results presented in this investigation, it could be concluded that FPM is a viable technique to obtain the matric suction profile for soils over a wide range of suction. The estimation of SWCC can be based on a single FPM measurement point, but at least two points are recommended to validate the estimation precision. The fitting parameter (n) can be predicted using the experimental dry density (95\% MDD in this study) and the specific gravity through the correlation provided in this study instead of using the trial and error technique. However, it is recommended that the provided correlation is to be further studied for various types of soils and conditions. It was noted that the matric suction is dramatically affected by the pore size distribution within a soil sample. Also, estimating SWCC allows utilizing and considering the effect of the matric suction in the design of foundations regarding bearing capacity and immediate settlement as shown in the reported equations. The matric suction can be utilized as a soil improvement technique by maintaining the subsurface soil beneath the foundation in unsaturated conditions.

The following may be recommended for future work:

- $\quad$ Extend the study of the provided correlation of the fitting parameter (n) to cover a wider range of soils.

- $\quad$ Develop and calibrate a numerical model for SWCC to yield SWCC for different types of soils [43].

- Validate the reported bearing capacity and settlement equations with unsaturated soil database reported in the literature.

- Investigate the effects of vegetation, plant roots, salinity, contaminations, among others, on the matric suction and, subsequently, on the bearing capacity of the foundation considering those effects in the bearing capacity equations.

\section{Acknowledgements}

The author gratefully acknowledges King Fahd University of Petroleum \& Minerals (KFUPM), Dhahran, Saudi Arabia, for supporting this study. Thanks are also extended to Dr. Habib-ur-Rehman Ahmed for supervising this study. 


\section{References}

[1] E. Buckingham, "Studies on The Movement of Soil Moisture," in Bulletin (United States. Bureau of Soils), no. 38. , United States: Washington, Govt. Print. Off., 1907, pp. 1-61.

[2] A. Tarantino, E. Romero, and Y.-J. Cui, Laboratory and Field Testing of Unsaturated Soils. Dordrecht, Netherlands: Springer Science+Business Media, B.V., 2009.

[3] ASTM-D6836, "Standard Test Methods for Determination of the Soil Water Characteristic Curve for Desorption Using Hanging Column, Pressure Extractor, Chilled Mirror Hygrometer, or Centrifuge," ASTM Int., vol. 04.09, pp. $1-22,2016$.

[4] R. Bulut and E. C. Leong, "Indirect Measurement of Suction," Geotech. Geol. Eng., vol. 26, no. 6, pp. 633-644, Dec. 2008.

[5] ASTM-D5298, "Standard Test Method for Measurement of Soil Potential (Suction) Using Filter Paper," ASTM Int., vol. 04.08, pp. 1-6, 2016.

[6] ASTM-D854, "Standard Test Methods for Specific Gravity of Soil Solids by Water Pycnometer," ASTM Int., vol. 04.08, pp. 1-8, 2014.

[7] ASTM-D4318, "Standard Test Methods for Liquid Limit, Plastic Limit, and Plasticity Index of Soils," ASTM Int., vol. 04.08, pp. 1-20, 2017.

[8] E. Polidori, "Relationship between The Atterberg Limits and Clay Content," Soils Found., vol. 47, no. 5, pp. 887896, 2007.

[9] ASTM-D6913/D6913M, "Standard Test Methods for Particle-Size Distribution (Gradation) of Soils Using Sieve Analysis," ASTM Int., vol. 04.09, pp. 1-34, 2017.

[10] ASTM-D422-63-(2007)e2, "Standard Test Method for Particle-Size Analysis of Soils (Withdrawn 2016)," ASTM Int., pp. 1-8, 2007.

[11] EPA-9081, "Cation-Exchange Capacity of Soils (Sodium Acetate), Part of Test Methods for Evaluating Solid Waste, Physical/Chemical Methods," United States Environ. Prot. Agency, vol. SW-846, no. 0, pp. 1-4, 1986.

[12] ASTM-D2487, "Standard Practice for Classification of Soils for Engineering Purposes (Unified Soil Classification System)," ASTM Int., vol. 04.08, pp. 1-12, 2011.

[13] D. M. Burmister, "Principles and Techniques of Soil Identification," in Annual Highway Research Board of Meeting, National Research Council, 1949, pp. 402-433.

[14] A. W. Skempton, “The Colloidal 'Activity' of Clays,” in 3rd Intern. Conf. Soil Mech. Found. Eng., 1953, pp. 57-61.

[15] A. A. B. Williams and G. W. Donaldson, "Building on Expansive Soils in South Africa: 1973-1980," in 4th International Conference on Expansive Soils, pp. 834-844, 1980.

[16] W. H. Bragg and W. L. Bragg, "The Reflection of X-rays by Crystals," Proc. R. Soc. A Math. Phys. Eng. Sci., vol. 88, no. 605, pp. 428-438, 1913.

[17] M. von Ardenne, "Das Elektronen-Rastermikroskop," Zeitschrift für Phys., vol. 109, no. 9-10, pp. 553-572, 1938.

[18] J. K. Mitchell and K. Soga, Fundamentals of Soil Behavior, 3rd ed. New Jersey: John Wiley \& Sons, Inc., 2005.

[19] F. Altuhafi, C. O'Sullivan, and I. Cavarretta, "Analysis of an Image-Based Method to Quantify the Size and Shape of Sand Particles," J. Geotech. Geoenvironmental Eng., vol. 139, no. 8, pp. 1290-1307, 2013.

[20] R. D. Hryciw, J. Zheng, and K. Shetler, "Particle Roundness and Sphericity From Images of Assemblies by Chart Estimates and Computer Methods," J. Geotech. Geoenvironmental Eng., vol. 142, no. 9, pp. 1-15, 2016.

[21] J. Zheng and R. D. Hryciw, "Soil Particle Size and Shape Distributions by Stereophotography and Image Analysis," Geotech. Test. J., vol. 40, no. 2, pp. 1-12, 2017.

[22] ASTM-D1557-12e1, "Standard Test Methods for Laboratory Compaction Characteristics of Soil Using Modified Effort (56,000 ft lbf/ft3 (2,700 kN-m/m3))," ASTM Int., vol. 04.08, pp. 1-14, 2012.

[23] E.-C. Leong, R. Kizza, and H. Rahardjo, "Measurement of Soil Suction Using Moist Filter Paper," in E3S Web of Conferences, vol. 9, pp. 1-6, 2016.

[24] L. David Suits, T. Sheahan, E. Leong, L. He, and H. Rahardjo, "Factors Affecting the Filter Paper Method for Total and Matric Suction Measurements," Geotech. Test. J., vol. 25, no. 3, pp. 1-12, 2002.

[25] K. V. Bicalho, A. I. Bertolde, K. F. Cupertino, J.-M. Fleureau, and A. G. Correia, "Single-Function Approach to Calibrating Whatman No. 42 Filter Paper Based on Suction Versus Water Content Relationships," Geotech. Test. J., vol. 38, no. 1, pp. 113-118, 2015. 
[26] M. T. van Genuchten, "A Closed-form Equation for Predicting the Hydraulic Conductivity of Unsaturated Soils," Soil Sci. Soc. Am. J., vol. 44, no. 5, pp. 892-898, 1980.

[27] D. G. Fredlund and A. Xing, "Equations for The Soil-Water Characteristic Curve," Can. Geotech. J., vol. 31, no. 4, pp. 521-532, Aug. 1994.

[28] S. K. Vanapalli and M. C. Catana, "Estimation of The Soil-Water Characteristic Curve of Coarse-Grained Soils Using One Point Measurement and Simple Properties," in International Symposium on Advanced Experimental Unsaturated Soil Mechanics, pp. 401-407, 2005.

[29] W. N. Houston, H. B. Dye, C. E. Zapata, Y. Y. Perera, and A. Harraz, "Determination of SWCC Using One Point Suction Measurement and Standard Curves," in Unsaturated Soils 2006, pp. 1482-1493, 2006.

[30] K.-B. Chin, E.-C. Leong, and H. Rahardjo, "A Simplified Method to Estimate The Soil-Water Characteristic Curve," Can. Geotech. J., vol. 47, no. 12, pp. 1382-1400, 2010.

[31] A. Pedarla, R. Acharya, T. Bheemasetti, A. J. Puppala, and L. R. Hoyos, "Influence of Mineral Montmorillonite on Soil Suction Modeling Parameters of Natural Expansive Clays,” Indian Geotech. J., vol. 46, no. 3, pp. 291-298, 2016.

[32] E. C. Leong and H. Rahardjo, "Review of Soil-Water Characteristic Curve Equations," J. Geotech. Geoenvironmental Eng., vol. 123, no. 12, pp. 1106-1117, 1997.

[33] D. G. Fredlund and H. Rahardjo, Soil Mechanics for Unsaturated soils, 1st ed. USA: John Wiley \& Sons, Inc., 1993.

[34] B. Loret and N. Khalili, "A Three-Phase Model for Unsaturated Soils," Int. J. Numer. Anal. Methods Geomech., vol. 24, no. 11, pp. 893-927, 2000.

[35] S. K. Vanapalli and F. M. O. Mohamed, "Bearing Capacity of Model Footings in Unsaturated Soils," in Experimental Unsaturated Soil Mechanics, Berlin, Heidelberg: Springer Berlin Heidelberg, 2006, pp. 483-493.

[36] S. K. Vanapalli and F. M. O. Mohamed, "Bearing Capacity and Settlement of Footings in Unsaturated Sands," Int. J. GEOMATE, vol. 5, no. 1, pp. 595-604, 2013.

[37] Z. Han, S. Han, W. T. Oh, and S. K. Vanapalli, "Modelling The Stress Settlement Behavior of Shallow Foundation in Unsaturated Sand Using Sigma/W And Plaxis," in 67th Canadian Geotechnical Conference, pp. 1-8, 2014.

[38] T. Vo and A. R. Russell, "Bearing Capacity of Strip Footings on Unsaturated Soils by The Slip Line Theory," Comput. Geotech., vol. 74, pp. 122-131, 2016.

[39] N. Khalili and M. Khabbaz, "Application of Effective Stress Concept to Unsaturated Soils," in 8th Australia New Zealand Conference on Geomechanics: Consolidating Knowledge, pp. 849-854, 1999.

[40] K. Terzaghi and R. B. Peck, "Soil Mechanics in Engineering Practice," in SpringerReference, vol. 1ère, Berlin/Heidelberg: Springer-Verlag, 1948, pp. 1-566.

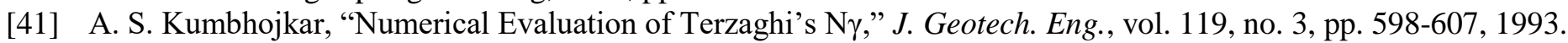

[42] J. H. Schmertmann, J. P. Hartmann, and P. R. Brown, "Improved Strain Influence Factor Diagrams.," J. Geotech. Eng. Div. ASCE., vol. 104, no. 8, pp. 1131-1135, 1978.

[43] J.-P. Gras, J.-Y. Delenne, F. Soulié, and M. S. El Youssoufi, "DEM and Experimental Analysis of The Water Retention Curve in Polydisperse Granular Media," Powder Technol., vol. 208, no. 2, pp. 296-300, 2011. 